\title{
Copper-induced expression, cloning, and regulatory studies of the plastocyanin gene from the cyanobacterium Synechocystis sp. PCC 6803
}

\author{
Linda M. Briggs, ${ }^{1}$ Vincent L. Pecoraro ${ }^{1}$ and Lee McIntosh ${ }^{2 *}$ \\ ${ }^{1}$ Department of Chemistry, University of Michigan, Ann Arbor, MI 48109, USA ; ${ }^{2}$ DOE Plant Research \\ Laboratory \& Department of Biochemistry, Michigan State University, East Lansing, MI 48824, USA \\ (*author for correspondence)
}

Received 18 June 1990; accepted in revised from 23 July 1990

Key words: plastocyanin, cyanobacteria, copper regulation

\begin{abstract}
Plastocyanin can be detected in Synechocystis sp. PCC 6803 when $3 \mu \mathrm{M}$ copper is added to the growth medium, BG-11. The plastocyanin gene (petE) was cloned from a genomic $\lambda$ EMBL 3 library by screening with the petE gene from Anabaena sp. PCC 7937. The Synechocystis 6803 petE gene is present as a single copy and, as deduced from the DNA sequence, encodes a precursor protein of 126 amino acids. The predicted 29 amino acid transit peptide shows substantial homology to the Anabaena 7937 transit peptide, thought to direct the plastocyanin precursor to the thylakoid lumen. Putative promoter sites -16 and -38 base pairs from the start of the pet $E$ gene have been identified. The deduced amino acid sequence has the greatest homology $(61 \%)$ to the green alga Scenedemus obliquus plastocyanin. Despite the lower homology, the copper binding residues and certain aromatic residues remain highly conserved. Northern hybridization analysis indicates that the Synechocystis sp. PCC 6803 petE gene is not transcriptionally regulated since the accumulation of petE mRNA appears to be independent of the copper concentration in the growth media. The possibility of an additional polypeptide needed to facilitate the electron transfer from plastocyanin to $\mathrm{P} 700^{+}$is also discussed.
\end{abstract}

\section{Introduction}

Plastocyanin, a small $\left(M_{\mathrm{r}} 10000\right)$ protein composed of a single polypeptide which contains one copper atom per molecule, is one of the mobile electron carriers connecting photosystem I (PS I) and photosystem II (PS II). Cupric $\left(\mathrm{Cu}^{2+}\right)$ plastocyanin oxidizes the membrane-bound cytochrome $b_{6} / f$ complex and then diffuses to the reaction center of PS I where the cuprous $\left(\mathrm{Cu}^{+}\right)$ plastocyanin reduces $\mathrm{P} 700^{+}[22,37]$.
In higher plants, nuclear-encoded plastocyanin is translated in the cytoplasm as a precursor protein that contains a transit peptide at the amino terminus. The transit peptide, which ranges from 34-80 amino acids depending on the organism, contains the information necessary for translocation to the thylakoid lumen [32]. During translocation the transit peptide is proteolytically removed leaving mature plastocyanin $(10000 \mathrm{kDa})$ in the thylakoid lumen [30].

Plastocyanin, which is constitutively produced 
in higher plants, is only found in some species of green algae and cyanobacteria $[12,15,26]$. The functional replacement for plastocyanin is a soluble iron-heme protein, cytochrome c553. Whether plastocyanin or cytochrome c553 functions in the cell is determined by the amount of copper available in the growth medium. Under conditions of copper deficiency the small $\left(M_{\mathrm{r}}\right.$ 9000 ) cytochrome c553 replaces plastocyanin as the reductant of $\mathrm{P} 700^{+}$[26]. Sandmann has shown, in some Nostoc cultures, that as the copper content is depleted with time the amount of plastocyanin decreases with a concomitant increase in cytochrome c553 [26]. Two different modes of metal-based regulation have been reported for plastocyanin in the literature. In the filamentous cyanobacterium Anabaena sp. PCC 7937 the steady-state level of petE transcript was shown to increase with an increased level of copper supplied to the growth medium [35]. The situation is very different in the green alga Chlamydomonas reinhardtii. PetE mRNA levels were independent of copper concentration; instead, plastocyanin is regulated by the degradation of the apoprotein in copper-deficient cultures [19].

Our studies of the petE gene and induction of plastocyanin synthesis in cyanobacteria is part of a larger effort to understand the molecular basis of gene regulation brought about by changes in the intracellular and extracellular concentrations of metal ions. Herein we (1) report the cloning of the pet $E$ gene, which is present as a single gene copy that encodes for a precursor protein of 126 amino acids; (2) demonstrate that the $\mathrm{Cu}^{2+}$ concentration regulates plastocyanin synthesis either at the translational or post-translational level and, (3) identify possible $c i s$-acting regions at -16 and -38 base pairs from the petE gene.

\section{Materials and methods}

\section{Materials}

Restriction endonucleases and other DNA-modifying enzymes were purchased from Bethesda Research Laboratories (Gaithersburg, MD) and
New England Biolabs (Beverly, MA) and used according to the suppliers' instructions. Nitrocellulose filters were obtained from Schleicher \& Schuell (Keene, NH). The dideoxy 'Sequenase' sequencing kit was obtained from United States Biochemical Corporation (Cleveland, $\mathrm{OH}$ ). Radiolabeled nucleotide was purchased from Amersham Corporation (Arlington Heights, IL). All sequence analysis was performed using the sequence analysis software package of the genetics computer group, University of Wisconsin [7].

\section{Growth conditions}

Synechocystis sp. PCC 6803 was grown in BG-11 with $5 \mathrm{mM}$ N-tris[hydroxymethyl] methyl-2aminoethane sulfonic acid (TES) [24]. Plastocyanin synthesis was induced by adding $\mathrm{CuSO}_{4}$ to $\mathrm{BG}-11$, to a final concentration in the medium of $3 \mu \mathrm{M} \mathrm{Cu}^{2+}$.

\section{Immunoblotting}

Cells harvested at room temperature were washed first in $10 \mathrm{mM}$ EDTA, $20 \mathrm{mM} \mathrm{N}$-[2-hydroxyethyl]piperazine- $\mathrm{N}$-[2-ethanesulfonic acid]) (HEPES) $\mathrm{pH} 7.5$, then in $1.5 \mathrm{M} \mathrm{KCl}, 5 \mathrm{mM}$ EDTA. After washing, the cells were brought to $0.1 \mathrm{mg} / \mathrm{ml}$ cholorophyll for lysis in $0.4 \mathrm{M}$ sucrose, $10 \mathrm{mM}$ EDTA, $20 \mathrm{mM}$ HEPES $\mathrm{pH} 7.5$ and treated with $2 \%$ lysozyme for 30 minutes at $31{ }^{\circ} \mathrm{C}$, followed by sonication with acid-washed glass beads (Sigma no. G2506, St Louis, MO).

Proteins were run on a 17.5 to $10 \%$ SDS-polyacrylamide gel, then transferred to mitrocellulose under 0.9 Amp current for 2 hours with cooling [33]. Protein concentrations were determined using the Lowry assay [16]. The nitrocellulose was probed with rabbit polyclonal antibodies raised against purified spinach plastocyanin by multiple subcutaneous injections into rabbits [34]. Antibody cross-reactivity was visualized using protein A alkaline phosphatase [3] (Sigma no. P9650). The portion of nitrocellulose containing Bio-Rad (Richmond, CA) low molecular weight markers was removed and stained with india ink. 


\section{Library screening}

Duplicate plaque lifts to nitrocellulose filters from a $\lambda$ EMBL3 phage library [6] were baked at $80^{\circ} \mathrm{C}$ in vacuo for $0.5-1$ hour followed by prehybridization at $55^{\circ} \mathrm{C}$ in $6 \times \mathrm{SSC}, 5 \times$ Denhardt's, $0.5 \% \mathrm{SDS}$, for 40 minutes. Hybridization with the random-primer-labeled probe [9] was carried out at $55^{\circ} \mathrm{C}$ in $3 \times \mathrm{SSC}, 0.1 \% \mathrm{SDS}$, $5 \times$ Denhardt's [17]. The hybridized plaque lifts were washed three times in $3 \times \mathrm{SSC}, 55^{\circ} \mathrm{C}$ totaling 34 minutes. Kodak XAR film was exposed to the washed filters using intensifying screens. Positive plaques were picked and rescreened using the same protocol. Phage DNA isolated from liquid culture [4] was subcloned into pBluescript obtained from Stratagene (La Jolla, CA).

\section{DNA isolation and Southern blotting}

Cesium-purified genomic DNA isolated from Synechocystis 6803 [38] was used for Southern blot analysis [32]. $10 \mu \mathrm{g}$ (per digest) of genomic DNA was run on $0.8 \%$ agarose gel, transferred to a nitrocelluose filter, baked at $80^{\circ} \mathrm{C}$ for 1 hour, and prehybridized using $6 \times \mathrm{SSC}, 5 \times$ Denhardt's, $0.5 \%$ SDS and $0.1 \mathrm{mg} / \mathrm{ml}$ denatured salmon sperm DNA. Overnight hybridization was performed at $65^{\circ} \mathrm{C}$ by adding the random-primerlabeled probe directly to the prehybridization solution. Filters were washed two times in $6 \times \mathrm{SSC}$ at $40-47^{\circ} \mathrm{C}$ for 20 minutes, two times in $1 \times \mathrm{SSC}$ at $65^{\circ} \mathrm{C}$ for 20 minutes and three times in $0.1 \times \mathrm{SSC}$ at $67-71^{\circ} \mathrm{C}$ for a total of 1 hour. Filters were exposed as described above.

\section{DNA sequencing}

CsCl-purified plasmid DNA prepared by the alkaline lysis method [17] was sequenced first using the chemical modification and chain cleavage method [18]. The dideoxy chain termination method with ${ }^{32} \mathrm{P}$-dATP as radiolabel [27] was used with primers based on sequence obtained from the chemical cleavage method.

\section{$R N A$ isolation and northern blotting}

Total RNA was isolated from Synechocystis 6803 according to the procedure of Golden [10]. Total RNA was run on a $1.2 \%$ agarose/formaldehyde gel, 3 hours at $100 \mathrm{~V}$. The gel was soaked in $10 \times \mathrm{SSC}$ for 45 minutes before setting up the overnight transfer to nitrocellulose. Nitrocellulose was prehybridized in $3 \times \mathrm{SSC}, 1 \times$ Denhardt's, $0.1 \%$ SDS, $30 \mathrm{mM}$ Tris, $0.1 \mathrm{mM}$ EDTA, $50 \%$ formamide, $40 \mu \mathrm{g} / \mathrm{ml}$ salmon sperm DNA. Randomprimer-labeled probe was added directly to the prehybridization solution for the overnight hybridization at $45^{\circ} \mathrm{C}$. Filters were washed for 3 hours at $55-60^{\circ} \mathrm{C}$ in $0.1 \times \mathrm{SSC}, 1$ hour at $70-72{ }^{\circ} \mathrm{C}$ in $0.1 \times \mathrm{SSC}$, then exposed as described above.

\section{Results}

\section{Plastocyanin induction}

When Synechocystis 6803 is grown in lab cultures containing $3 \mu \mathrm{M}$ copper, plastocyanin can be detected. Induction of plastocyanin synthesis was seen by comparison of cell extracts from Synechocystis 6803 grown with and without addition of copper to the growth medium BG-11 [24]. Lanes 2 and 3 of the immunoblot in Fig. 1 show whole cell extracts from cells grown in BG-11, with $3 \mu \mathrm{M} \mathrm{Cu}^{2+}$. Lane 4 is whole cell extract from cells grown in unsupplemented BG-11, that is $0.3 \mu \mathrm{M} \mathrm{Cu}^{2+}$. The plastocyanin band clearly visible in lanes 2 and 3 (at approximately $M_{\mathrm{r}}$ $10000)$ is absent in lane $4(160 \mu \mathrm{g}$ total protein lanes $2,3,4)$. The nitrocellulose filter shown in Fig. 1 was incubated with rabbit polyclonal antibodies raised against purified spinach plastocyanin. Spinach plastocyanin, $M_{\mathrm{r}} 10400$ [24], in lane $1(0.5 \mu \mathrm{g}$ protein) has a pI of 4.2 [23]. Synechocystis 6803 plastocyanin has a calculated [7] pI of 5.6.

\section{Gene cloning}

The petE gene from Synechocystis 6803 was cloned from a $\lambda$ EMBL3 genomic library [6] by screening with the Anabaena 7937 petE gene, which was a generous gift from J.Van der Plas [35]. The 


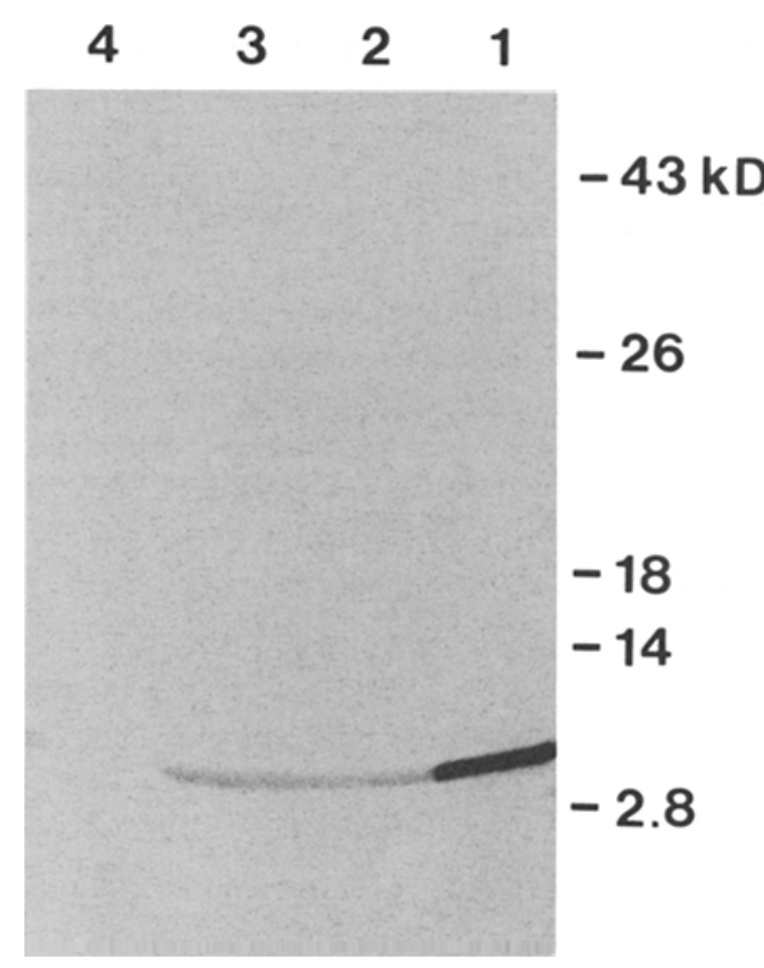

Fig. 1. Western blot of Synechocystis sp. PCC 6803 total cellular protein. Proteins run on a 17.5 to $10 \%$ polyacrylamide gradient, transferred to nitrocellulose membrane, then incubated with antibodies raised against spinach plastocyanin. Lane $1,0.5 \mu \mathrm{g}$ spinach plastocyanin; lanes 2 and 3 , total cellular protein from cells grown in BG-11 $+3 \mu \mathrm{M} \mathrm{Cu}^{+2}$ (cells used in RNA prep); lane 4, total cellular protein from Synechocystis 6803 grown in BG-11.160 $\mu$ g total protein in all Synechocystis lanes.
Anabaena probe, a 600 bp Hind III fragment consisting of the $400 \mathrm{bp}$ coding region for plastocyanin and the $200 \mathrm{bp}$ flanking $3^{\prime}$ region, was first used to probe genomic Synechocystis DNA digested with Hind III, Kpn I, Bam HI, Hinc II, $N c o$ I, $X b a$ I, and Eco RI. A single hybridization signal for each digest showed early signs that plastocyanin was encoded by a single copy and served to establish hybridization conditions with the heterologous probe (results not shown). The same probe was used to screen plaque blots at $55^{\circ} \mathrm{C}, 3 \times \mathrm{SSC}$. Southern hybridization analysis of phage DNA isolated from one of the positives, a $17 \mathrm{~kb} \mathrm{Sal} \mathrm{I} \mathrm{insert} \mathrm{in} \mathrm{EMBL3,} \mathrm{showed} \mathrm{strong}$ signals at $4 \mathrm{~kb} \mathrm{Nco} \mathrm{I,} 9 \mathrm{~kb}$ Eco RI and $1.8 \mathrm{~kb}$ $H$ ind III. The $9 \mathrm{~kb} E c o$ RI and $1.8 \mathrm{~kb} H$ ind III bands were isolated from preparative agarose gels and subcloned into pBluescript.

Further restriction digests and Southern hybridization of the $1.8 \mathrm{~kb}$ Hind III subclone narrowed the petE region to a $500 \mathrm{bp}$ Nco I/Hind III fragment. End labeling with ${ }^{32} \mathrm{P}$ dATP followed by chemical modification and chain cleavage sequencing [18] revealed the petE gene was truncated just upstream of the copperbinding site by the Hind III site. Specific primers for dideoxy chain termination sequencing [27] of the $9 \mathrm{~kb}$ Eco RI subclone were designed based on the initial sequence obtained. Three sets of primers were made for sequencing the entire region (shown in Fig. 2) several times in both directions.

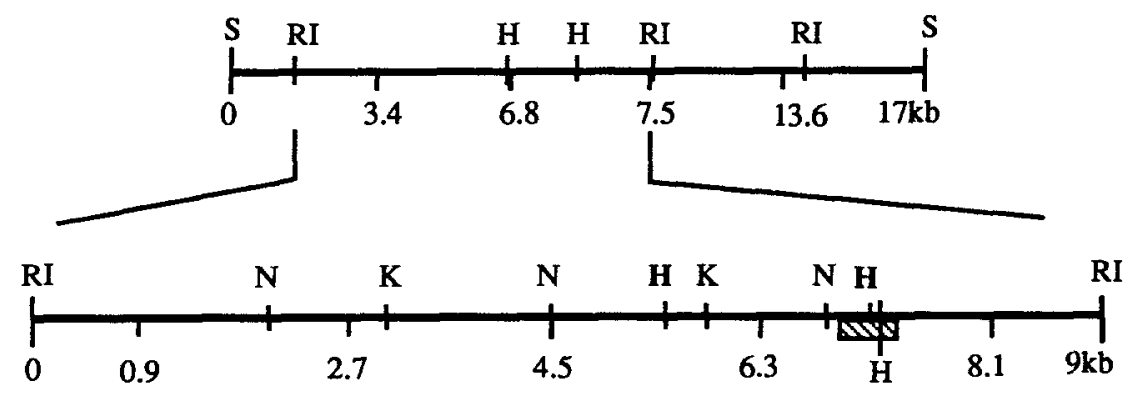

Fig. 2. Top: restriction map of the $17 \mathrm{~kb}$ clone isolated from the bacteriophage EMBL3 genomic library. Bottom: restriction map of the $9 \mathrm{~kb}$ Eco RI subclone. The $1.8 \mathrm{~kb}$ Hind III fragment shows the relative position of the plastocyanin gene denoted as ( $\square$ ). Restriction sites are as follows: $\mathrm{H}=H$ ind III; $\mathrm{K}=K p n \mathrm{I} ; \mathrm{N}=N c o \mathrm{I} ; \mathrm{RI}=E c o \mathrm{RI} ; \mathrm{S}=S a l \mathrm{I}$. 
$\begin{array}{lll}-80 & -60 & -40\end{array}$

AAA AAC GTC CCT GAT CGC CTT TTT GGG CAC GGA GTA GGG CGT TAC CCC GGC CCG TTC AAC

$$
\begin{array}{llll}
-20 & -1 & 10 & 20
\end{array}
$$

CAC AAG TCC CTA TAG ATA CAA TCG CCA AGA AGT ATG TCT AAA AAg TTT TTA ACA ATC CTC $\begin{array}{llllll}30 & 40 & 50 & 60 & 70 & 80\end{array}$ GCT GGC CTT CTG CTG GTG GTC TCC AGT TTC TTT TTA TCC GTG AGC CCC GCT GCC GCT GCC

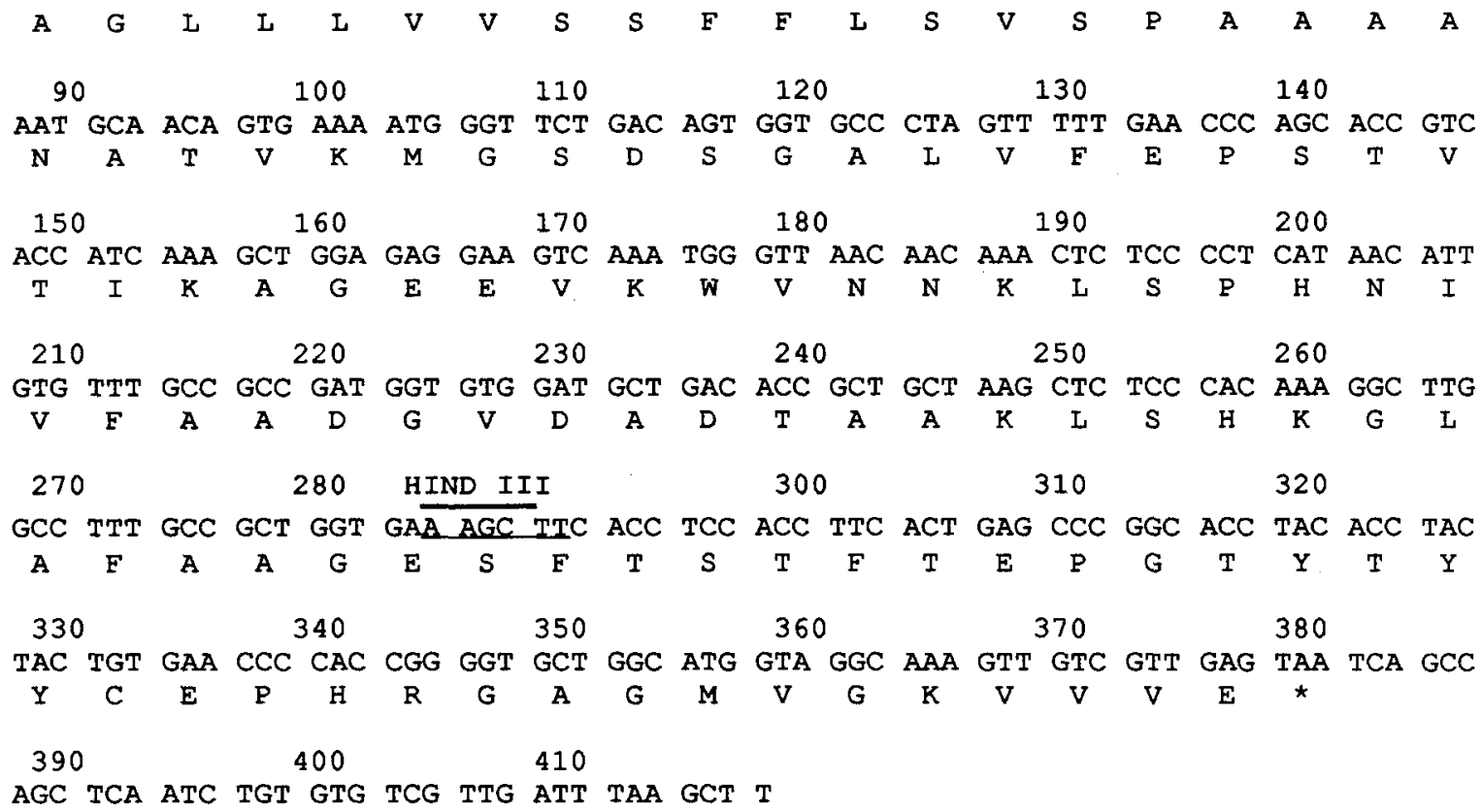

Fig. 3. Nucleotide sequence of the Synechocystis sp. PCC 6803 petE gene and deduced amino acid sequence below the DNA coding region. The arrowhead indicates the assumed processing site for removal of the transit peptide. Putative promoter sequences are underlined. Hind III site is shown near the copper binding site.

\section{PetE gene}

The nucleotide sequence coding for the Synechocystis 6803 petE gene is shown in Fig. 3. The methionine seven amino acid residues beyond the start of the open reading frame is probably the start codon since there are no others in this vicinity. The arrowhead in Fig. 3 shows the putative processing site for removal of the transit peptide. This site was deduced from comparison with the Anabaena transit sequence (see Discussion). A portion of the region upstream from the start codon is noteworthy since it bears resemblance to putative promoter sequences reported for ferredoxin genes from Anabaena 7120, 7937 and Synechococcus 7942 [36]. Comparisons are shown in Fig. 4. The sequence TAGATA, the ' -10 ' region, is found 16 base pairs upstream from the ATG, and spaced 16 base pairs further upstream the sequence CCCGTT is found, labeled the ' -35 ' region.

Southern hybridization analysis of Synechocystis genomic DNA with the random primer labeled $1.8 \mathrm{~kb}$ Hind III fragment shown in Fig. 5 indicates that the pet $E$ gene is present in a single copy. The $1.8 \mathrm{~kb}$ Hind III fragment consists of the $400 \mathrm{bp}$ coding region at its $3^{\prime}$ end and the remaining $1.4 \mathrm{~kb}$ being the upstream $5^{\prime}$ region. For the Hind III, Eco RI, and Kpn I digests a single hybridization signal appears at $1.8 \mathrm{~kb}, 8.9 \mathrm{~kb}$ and $2.2 \mathrm{~kb}$, respectively. There are two bands present in the Nco I digest because the first and more 


\begin{tabular}{|c|c|c|c|c|}
\hline & $"-35 "$ & & $"-10 "$ & \\
\hline TTT & CAAGTT & ATATACTTGGATTTTTCTCG & TAGTAT & CAGAATTG - 98bp ATG - Ferredoxin \\
\hline TTT & CAAGTT & АTATACTTTGATTTTTCCCG & TAGTAT & CAGAATTG - 98bp ATG - Ferredoxin \\
\hline GGC & GTT & TGAGCCGT-GATTAC-CCC- & TACGAA & CTTTCCGG- 169bp ATG-Ferredoxin \\
\hline GC & GTT & $--\mathrm{CCCA}-$ & TAGTAT & CAATGGGA - 63bp ATG - Ferredoxin \\
\hline GG- & CCCGTT & CAACCAC--- AAGTCCCTA & TAGATA & CAATCGCCA - 6bp ATG - Plastocyanin \\
\hline & $\begin{array}{l}\text { TTGTCA } \\
\text { TTGACA }\end{array}$ & $\begin{array}{l}\text { TATTTGGTGTCGA } \\
-\end{array}$ & $\begin{array}{l}\text { TATTTA } \\
\text { TATAAT }\end{array}$ & $\begin{array}{l}\text { AAATGAAA - 6bp ATG - Plastocyanin } \\
-\ldots-\text { Consensus } E \text {. coli promoter }\end{array}$ \\
\hline
\end{tabular}

Fig. 4. Comparison of putative promoter sequences for ferredoxin and plastocyanin from (1) Anabaena sp. PCC 7120; (2) Anabaena sp. PCC 7937; (3) Synechococcus sp. PCC 7942 P1; (4) Synechococcus sp. PCC 7942 P2 [35]; (5) Synechocystis sp. PCC 6803; (6) Anabaena sp. PCC 7937 [34]; (7) Procaryotic promoter sequence. The '- 10' and '- 35 ' regions are based on consensus procaryote sequences. The sequences shown in lines 3 and 4 are two putative promoters for the same gene in Synechoccus 7942 .

Gaps are inserted to maximize homology.

intense signal at $2.2 \mathrm{~kb}$ has a larger overlapping area with probe than the second less intense signal at $4.5 \mathrm{~kb}$ which is where the plastocyanincoding region actually lies (see Fig. 2).

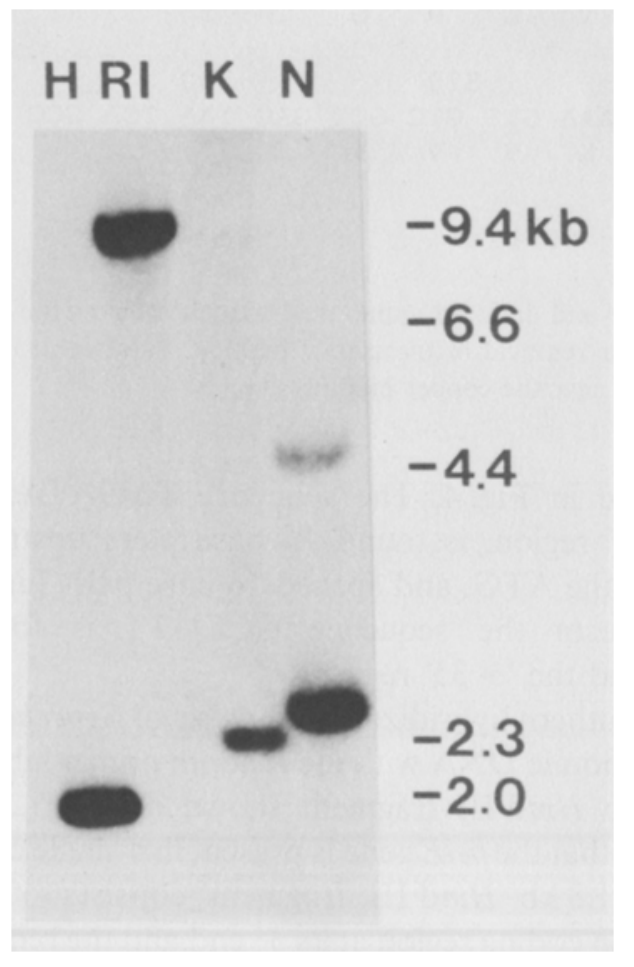

Fig. 5. Southern hybridization of $1.8 \mathrm{~kb}$ Hind III fragment to total Synechocystis sp. PCC 6803 genomic DNA run on $0.8 \%$ agarose gel blotted to nitrocellulose, hybridization at $65^{\circ} \mathrm{C}$, $6 \times$ SSC. Genomic DNA was digested with $\mathrm{H}=$ Hind III; $\mathrm{RI}=E c o \mathrm{RI} ; \mathrm{K}=K p n \mathrm{I}$; and $\mathrm{N}=N c o \mathrm{I}$. Molecular size markers in $\mathrm{kb}$ are lambda DNA digested with Hind III.

\section{Transcriptional analysis}

Northern hybridization analysis was performed to compare steady-state petE mRNA levels from cells grown with and without additional copper in the growth medium. Total RNA isolated from cells grown in BG-11 containing $0.3 \mu \mathrm{M}$ and $3 \mu \mathrm{M} \mathrm{Cu}{ }^{+2}$ was separated and denatured on a $1.2 \%$ agarose/formaldehyde gel, then transferred to a nitrocellulose filter. The nitrocellulose filter

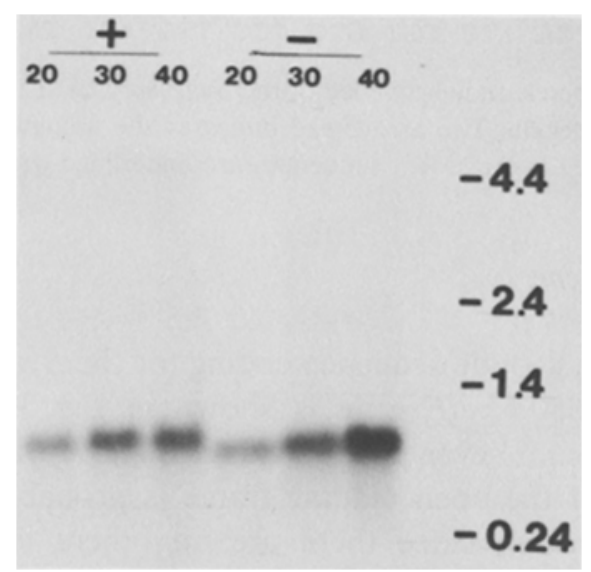

Fig. 6. Northern hybridization analysis of total RNA from Synechocystis sp. PCC 6803 grown with and without $\mathrm{Cu}^{2+}$ added to the growth medium BG-11. Total RNA was separated on a $1.2 \%$ agarose/formaldehye gel transferred to nitrocellulose and hybridized with a $380 \mathrm{bp}$ fragment derived from the Synechocystis 6803 pet $E$ gene. The first three lanes labeled + are RNA from cells grown with $3 \mu \mathrm{M} \mathrm{Cu}^{2+}$ in BG-11 20, $30,40 \mu \mathrm{g}$ respectively. The next three lanes labeled - are RNA from cells grown in BG-11 $\left(0.3 \mu \mathrm{M} \mathrm{Cu}^{2+}\right)$ also 20, 30, $40 \mu \mathrm{g}$ respectively. 
was prehybridized $\left(42^{\circ} \mathrm{C}\right)$ followed by overnight hybridization $\left(45^{\circ} \mathrm{C}, 50 \%\right.$ formamide). Results of the northern hybridization, using a $380 \mathrm{bp}$ section of the petE coding region as a probe, indicate a single specific transcript between 655-755 bases as shown in Fig. 6. Three total RNA lanes $(20,30,40 \mu \mathrm{g})$ were run for each growth condition, with the increasing band intensities paralleling the increasing amount of total RNA per lane. There is no change in the steadystate petE mRNA level as a function of copper available to the cell.

\section{Discussion}

In a survey of 15 species of cyanobacteria for formation of plastocyanin and cytochrome c553 Sandmann observed plastocyanin in Synechocystis ATCC 27178 [26]. We report conclusive evidence for the presence of plastocyanin in another strain, Synechocystis 6803, namely plasto- cyanin synthesis due to an increased level of copper in the growth media. The petE gene was cloned from a genomic phage library using the Anabaena pet $E$ gene as a probe. At the nucleotide level the $600 \mathrm{bp}$ region of the Anabaena probe shows $62 \%$ identity to the Synechocystis petE gene [7]. In Synechocystis 6803 plastocyanin is encoded as a 126 amino acid precursor protein with a probable 29 amino acid transit sequence at the amino terminus. The transit sequence shows substantial homology to the same region of the 139 amino acid precursor plastocyanin reported for Anabaena 7937 [35]. In higher plants, where plastocyanin is nuclear-encoded, the transit peptide serves to direct the precursor protein across the chloroplast and thylakoid membranes. The chloroplast and thylakoid import domains of the transit peptide have been been identified using the pea chloroplast system [29]. Even though the chloroplast envelope is missing in cyanobacteria the thylakoid membrane must be traversed for plastocyanin to function as the reductant of

\begin{tabular}{|c|c|c|c|c|c|c|}
\hline & 1 & 10 & 20 & 30 & 40 & \\
\hline Synechocystis & nAt VKMGsD & sGaLVFEPSt & VTIKAGEeVk & WvNNk IsPHN & IVFaaD ...g & \\
\hline $\begin{array}{l}\text { Anabaena } \\
\text { scenedesmus }\end{array}$ & $\begin{array}{l}\text { etytVKLGsD } \\
\text { AnVKLGaD }\end{array}$ & $\begin{array}{l}\text { kGLLVFEPak } \\
\text { sGaLvFEPat }\end{array}$ & $\begin{array}{l}\text { ITIKPGDEVe } \\
\text { VTIKAGDsVT }\end{array}$ & $\begin{array}{l}\text { FNNKVPPBN } \\
\text { WtNNAGEPHN }\end{array}$ & $\begin{array}{l}\text { VVFDat InPA } \\
\text { IVFDEDaVPA. }\end{array}$ & \\
\hline $\begin{array}{l}\text { Scenedesmus } \\
\text { Chlorella }\end{array}$ & dvtVKLGaD & sGaLvFEPSs & VTIKAGEtVT & WVNNAGFPHN ? & IVFDEDEVP. . & \\
\hline norpha & aAiVKLGgD & DGsLaF vPnn & iTVgAGEsIe & FINNAGEPRN & IVFDEDaVPA & \\
\hline & & DGsLa & kIv & FkNNAGEPHN & VIFDE & \\
\hline cia & veVlLGgg & DGsLaF IPgD & fsVasGEeIv & FkNNAGFPHN & VVFDEDEIP $\mathbf{S}$ & \\
\hline Sil & AeVILGss & DGgLaF VPSD & IsIasGEkIT & FkNNAGFPHN & dlFDEDeVPA & \\
\hline \multirow[t]{2}{*}{ Consensus } & G-D & FEPSD & GE $--T$ & F-NNAGFPEN & IVFDED-VPA & \\
\hline & 50 & 60 & 70 & 80 & 90 & \\
\hline $\begin{array}{l}\text { Synechocystis } \\
\text { Anabaena }\end{array}$ & $\begin{array}{l}\text { vdadtAakLS } \\
\text { ksadlAkSLS }\end{array}$ & $\begin{array}{l}\text { HkgLafAaGE } \\
\text { HkqLImsPGq }\end{array}$ & $\begin{array}{l}\text { SFtsTFTE. } \\
\text { StStTFpada }\end{array}$ & $\begin{array}{l}\text { - PGTYL YYCE } \\
\text { PAGdYSFYCE }\end{array}$ & $\begin{array}{l}\text { PHrGAGMVGK } \\
\text { PHIGAGMVK }\end{array}$ & \\
\hline & gVnAdaLS & HDDYLNAPGE & SYtakF...D & TAGEYGYFCE & PHQGAGMVGK & Vivg \\
\hline & aLs & HEDYLNAPGE & SYSakF...D & TAGTYGYFCE & PHQGAGMkGt & ITVq \\
\hline orpha & GVD. & aEDyLNskGq & tvvrkL...t & TPGTYGVYCD & PHsGAGMkmt & ITVq. \\
\hline$O F$ & GVDVskisMS & eEDLLNAKGE & tFeVaLsDK. & . .GeYtFYCs & PHQGAGMVGK & ViVn. \\
\hline & GVD & EEDLLNAPGE & S tYkVTLTEK. & . .GTYkFYCs & PHQGAGMVGK & VTVn \\
\hline & & eEDLLNAPGE & EYSVTLTEK. & . .GTYkFYCa & PHaGAGMVGK & \\
\hline & GVDV - A- & HEDLLNAPGE & SYSVT-TEKD & TAGTYGFYCE & HQGAGMVGK & \\
\hline
\end{tabular}

Fig. 7. Alignment of amino acid sequences of plastocyanin from cyanobacteria, green algae, and chloroplasts. (1) Synechocystis sp. PCC 6803; (2) Anabaena sp. PCC 7937 [34]; (3) Scenedesmus obliquus [20]; (4) Enteromorpha prolifera [27]; (5) Chlorella fusca [13]; (6) Populus nigra italica [10]; (7) Silene pratensis [29]; (8) Spinacia oleracea [24]; (9) Consensus = consensus amino acid sequence. Consensus residues in capital letters, nonconsensus residues in lower-case letters, alignment has a gap weight $=3.0$ and length weight $=0.1$ [7]. Active site residues are in bold type, numbering is not based on a particular sequence. 
$\mathrm{P} 700^{+}$. Therefore, a transit peptide or $\mathrm{N}$-terminal extension is thought to direct transport of plastocyanin across the thylakoid membrane in cyanobacteria. There are striking similarities in comparing the N-terminal extensions of Synechocystis and Anabaena plastocyanin (Fig. 7), namely the pair of positively charged residues, lysines or arginines spaced eight amino acids upstream from the conserved LLVVSSF sequence which is spaced 4-5 amino acids from the putative [P-X-A-A-A] processing site. Furthermore, cleavage at this site would result in a mature protein of 97 amino acids, nearly all higher-plant plastocyanins are 99 residues, Chlorella fusca [14] and Enteromorpha prolifera [28] are 98 and Scenedesmus obliquus [21] is 97 residues. For purposes of comparison we are assuming glutamine is the first amino acid. Comparison of the cyanobacterial transit sequences to those available for higher plants show only a general conservation of hydrophobic and neutral amino acids with basic residues at the beginning of the thylakoid domain. Otherwise, the cyanobacterial transit sequences show little homology to the much larger higherplant sequences which are highly conserved.

Figure 6 displays 8 mature plastocyanin sequences and a calculated consensus sequence, the protein sequences being aligned with gaps inserted to maximize similarity [7]. Synechocystis plastocyanin has the greatest homology to Scenedesmus plastocyanin [21] (61\% identical amino acids), followed by Anabaena where $56 \%$ of the amino acids are identical. Homology to higher-plant sequences is reduced to an even greater extent with a range of $38-50 \%$ identical residues for all of the higher-plant sequences. The sequence divergence among the lower organisms is in contrast to the higher-plant sequences which are highly conserved (usually $>75 \%$ similarity). Both the Anabaena and Synechocystis plastocyanin lack the so called 'acidic patch' (residues 42-45) so highly conserved among the higherplant sequences, and thought to be important for protein recognition [2]. However, unlike the basic Anabaena 7937 protein, with a pI of 7.5-8.0 [12], Synechocystis 6803 plastocyanin has a calculated pI of 5.6 [7], which is consistent with other unicellular cyanobacteria [12]. The unusual variation in isoelectric point for plastocyanin, and cytochrome $c 553$ which varies in a parallel manner [12] is certainly interesting from a taxonomical view point. But more to the heart of the matter is how this relates to the functioning of plastocyanin as a catalyst for electron transfer to $\mathrm{P} 700^{+}$. The large diversity seen in plastocyanin amino acid sequences among procaryotes and eucaryotes is in contrast to the very highly conserved amino acid sequences for the apoprotein ( $p s a \mathrm{~A}$ and $p s a \mathrm{~B}$ ) of the PS I reaction center [5]. This seems a bit unusual, if they are physiological partners, unless an additional polypeptide facilitates electron transfer to $\mathrm{P} 700^{+}$. This idea has been proposed in the past, when purified PS I particles, lacking the $20 \mathrm{kDa}$ polypeptide (subunit III), were inactive in plastocyanin or cytochrome c553 mediated NADP photoreduction [1]. More recent evidence by Malkin supports this as well; his results show that plastocyanin can be covalently crosslinked to PS I particles by a single specific PS I subunit, the $19 \mathrm{kDa}$ polypeptide, a protein located on the lumenal side of the membrane [39].

Along with the characteristic copper-binding residues His-38, Cys-82, His- 85 , Met-90, the aromatic residues at positions 30,81 , as well as Tyr 78 ( 3 amino acids upstream from cys),

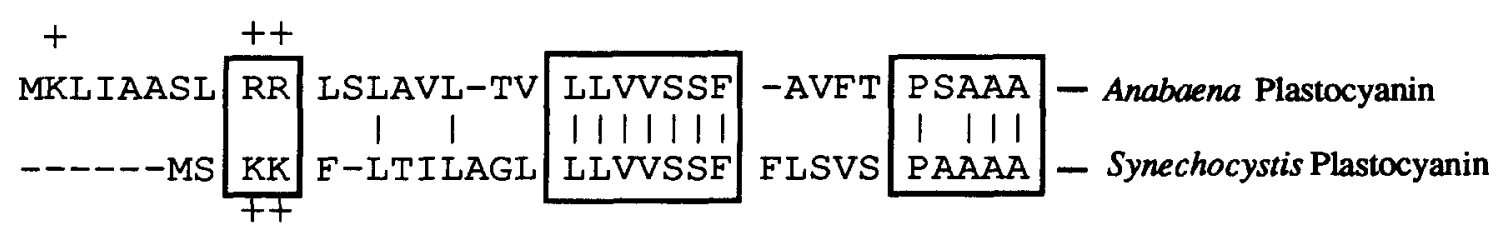

Fig. 8. Alignment of transit peptide sequences from Anabaena sp. PCC 7937 and Synechocystis sp. PCC 6803. The + indicates positively charged residues at neutral $\mathrm{pH}$. Areas are boxed to show similarities. Gaps are inserted to maximize homology. 
Phe 15, and Phe 42 continue to be invariant in the growing collection of plastocyanin sequences, (numbering here is based on Synechocystis 6803 plastocyanin). Tyrosine, phenylalanine, and tryptophan have been pinpointed because an interaction of the $\pi$-system of these residues may provide an electron transfer pathway [8].

The similarities between the plastocyanin $5^{\prime}$ non-coding region and putative promoter sequences for ferredoxin (Fig. 4) are particularly interesting since ferredoxin like plastocyanin is also metal cation regulated. Under iron-limiting conditions ferredoxin is replaced by flavodoxin in green algae and cyanobacteria [13]. Ferredoxin, a small $\left(M_{\mathrm{r}} 12000\right)$ iron-sulfur protein opposite plastocyanin on the stromal side of the thylakoid membrane, shuttles electrons from PS I to $\mathrm{NADP}^{+}$through the catalyst ferredoxin $\mathrm{NADP}^{+}$reductase [13]. As seen in the sequence comparison shown in Fig. 4 the TAGATA sequence 16 base pairs directly in front of the start codon is similar to the TATAAT ' - 10' consensus sequence for procaryotes. This, along with the CCCGTT sequence that is positioned 16 base pairs further upstream, is similar to the putative promoter sequence reported for ferredoxin [36] differing by 2 nucleotides in each case. On the other hand, the $5^{\prime}$ non-coding region upstream from the Anabaena 7937 pet $E$ gene shows greater similarity to the consensus $E$. coli promoters than to the putative ferredoxin promoters. Also, in the Synechocystis 6803 sequence shifting the ' -10 ' region two base pairs upstream affords the sequence TATAGA, which closely resembles the E. coli ' - 10' region.

It is clear from the immunoblotting results that plastocyanin accumulation in Synechocystis 6803 is regulated by the copper available to the cells. Total RNA isolated from the same cells used in the protein analysis shows no difference in steadystate petE transcript levels. It seems then that copper is a factor in the regulatory process posttranscriptionally, as it is in the green alga Chlamydomonas reinhardtii, where there is no change in petE mRNA levels as the copper concentration decreases. Plastocyanin does not accumulate under copper deficiency because the apoprotein is rapidly degraded [19]. On the other hand, cytochrome c553 is transcriptionally regulated in Chlamydomonas [20]. Even though the growth conditions for Anabaena and Synechocystis were not identical, the evidence suggests that the plastocyanin regulatory process is quite different in the two cyanobacteria. In Anabaena 7937 there is a difference in mid log phase petE mRNA level when grown in $1 \mu \mathrm{M}$ versus no $\mathrm{Cu}^{+2}$ [35]. Yet in Synechocystis 6803 there is not a difference in mid $\log$ phase petE mRNA level in $3 \mu \mathrm{M}$ versus $0.3 \mu \mathrm{M} \mathrm{Cu}{ }^{+2}$ as present in 'normal' BG-11. Furthermore, in Synechocystis 6803 the effect of changing copper concentration is seen at the protein level. The data suggest an interesting paradox, the Synechocystis 6803 plastocyanin regulatory process and, to a lesser extent, the amino acid sequence show a greater similarity to the eucaryotic green alga than to the closer phylogenetic relative, the filamentous cyanobacterium Anabaena.

\section{Acknowledgements}

The authors wish to thank Professor Eran Pickersky for technical assistance and useful discussions. This work was supported in part by a G.D. Searle Scholars Award administered by the Chicago Community Trust to V.L.P. and Department of Energy contract DE-ACO2-76ERO-1338 to L.M.

\section{References}

1. Bengis C, Nelson N: Subunit structure of chloroplast photosystem I reaction center. J Biol Chem 252: 4564-4569 (1977).

2. Beoku-Betts D, Chapman SK, Knox CV, Sykes AG: Concerning the binding site on plastocyanin for its natural redox partner cytochrome f. J Chem Soc Chem Commun 767: 1150-1152 (1983).

3. Blake MS, Johnston KH, Russell-Jones GJ, Gotschlich EC: A rapid, sensitive method for detection of alkaline phosphatase-conjugated anti-antibody on western blots. Anal Biochem 136: 175-179 (1984).

4. Blattner FR, Williams BG, Blechl AE, DennistonThompson K, Farber HE, Furlong L, Grunwald DJ, Kiefer DO, Moore DD, Schumm JW, Sheldon EL, Smithies O: Charon phages: safer derivatives of bacteriophage lambda for DNA cloning. Science 196: 161-169 (1977). 
5. Cantrell A, Bryant DA: Molecular cloning and nucleotide sequence of the psaA and psaB genes of the cyanobacterium Synechococcus sp PCC 7002. Plant Mol Biol 9: 453-468 (1987).

6. Debus RJ, Barry BA, Babcock GT, McIntosh L: Sitedirected mutagenesis identifies a tyrosine radical involved in the photosynthetic oxygen-evolving system. Proc Natl Acad Sci USA 85: 427-430 (1988).

7. Devereux J, Haeberli P, Smithies O: A comprehensive set of sequence analysis programs for the VAX. Nucl Acids Res 12: 387-395 (1984).

8. Farver O, Shahak Y, Pecht I: Electron uptake and delivery sites on plastocyanin in its reaction with the photosynthetic electron transport system. Biochemistry 21: 1885-1890 (1982).

9. Feinberg AP, Vogelstein B: A technique for radiolabelling DNA restriction endonuclease fragments to high specific activity. Anal Biochem 132: 6-13 (1984).

10. Golden SS, Brusslan J, Haselkorn R: Genetic engineering of the cyanobacterial chromosome. Meth Enzymol 153: 215-231 (1987).

11. Guss JM, Freeman HC: Structure of oxidized poplar plastocyanin at $1.6 \AA$ resolution. J Mol Biol 169: 521-563 (1983).

12. Ho KK, Krogman DW: Electron donors to P700 in cyanobacteria and alga: an instance of unusual genetic variability. Biochim Biophys Acta 766: 310-316 (1984).

13. Hutber GN, Hutson KG, Rogers LJ: Effects of iron deficiency on levels of two ferrodoxins and flavodoxin in Cyanobacterium. FEMS Microbiol Lett 1: 193-196 (1977).

14. Kelly J, Ambler RP: The amino acid sequence of plastocyanin from Chlorella fusca. Biochem J 143: 681-690 (1974).

15. Kwok KH, Ulrich EL, Krogman DW, Gomez-Lojero C: Isolation of photosynthetic catalysts from cyanobacteria. Biochim Biophys Acta 545: 237-249 (1979).

16. Lowry OH, Rosebrough NJ, Farr LA, Randall RJ: Protein measurement with the folin phenol reagent. J Biol Chem 193: 265-274 (1951).

17. Maniatis T, Fritsch EF, Sambrook J: Molecular Cloning: A Laboratory Manual. Cold Spring Harbor Laboratory, Cold Spring Harbor (1982).

18. Maxam AM, Gilbert W: Sequencing end-labeled DNA with base-specific chemical cleavages. Meth Enzymol 65: 499-560 (1980).

19. Merchant S, Bogorad L: Rapid degradation of apoplastocyanin in $\mathrm{Cu}$ (II) deficient cells of Chlamydomonas reinhardtii. J Biol Chem 261: 15850-15853 (1986).

20. Merchant S, Bogorad L: Metal ion regulated gene expression: use of plastocyaninless mutant of Chlamydomonas reinhardtii to study the $\mathrm{Cu}(\mathrm{II})$ dependent expression of cytochrome c-552. EMBO J 6: 2531-2535 (1987).

21. Moore JM, Chazin WJ, Powls R, Wright PE: 'H NMR studies of plastocyanin from Scenedesmus obliquus: complete sequence-specific assignment, secondary structure analysis, and global fold. Biochemistry 27: 7806-7816 (1988).

22. Mordhay A, Shneyour A: On the site of action of plastocyanin in isolated chloroplasts. Biochim Biophys Acta 226: 498-500 (1971).

23. Ramshaw JAM, Brown RH, Seawen MD, Boulter D: Higher plant plastocyanin. Biochim Biophys Acta 303: 269-273 (1972).
24. Rippka R, Deruelles J, Waterbury JB, Herdman M, Stanier RY: Generic assignments, strain histories and properties of pure cultures of cyanobacteria. J Gen Microbiol 111: 1-61 (1979).

25. Rother D, Jansen T, Tyagi A, Tittgen J, Hermann RG: Plastocyanin is encoded by an uninterrupted nuclear gene in spinach. Curr Genet 11: 171-176 (1986).

26. Sandmann G: Formation of plastocyanin and cytochrome c553 in different species of blue-green algae. Arch Microbiol 145: 76-79 (1986).

27. Sanger F, Coulson AR, Barrel BG, Smith AJ, Roe BA: Cloning in single-stranded bacteriophage as an aid to rapid DNA sequencing. J Mol Biol 143: 161-178 (1980).

28. Simpson RJ, Moritz RL, Nice EC, Grego B, Yoshizaki F, Sugimura Y, Freeman HC, Murata M: Complete amino-acid sequence of plastocyanin from a green alga, Enteromorpha prolifera. Eur J Biochem 137: 497-505 (1986).

29. Smeekens S, Bauerle C, Hageman J, Keegstra D, Weisbeek P: The role of the transit peptide in the routing of precursors toward different choloroplast compartments. Cell 46: 365-376 (1986).

30. Smeekens $S$, de Groot $M$, van Binsbergen J, Weisbeek P: Sequence of the precursor of the chloroplast thylakoid lumen protein plastocyanin. Nature 317: 456-458 (1985).

31. Smeekens S, Weisbeek P: Protein transport towards the thylakoid lumen: posttranslational translocation in tandem. Phtosynth Res 16: 177-186 (1988).

32. Southern EM: Detection of specific sequences among DNA fragments separated by gel electrophoresis. J Mol Biol 98: 503-517 (1975).

33. Towbin $\mathrm{H}$, Stahelin T, Gordon J: Electrophoretic transfer of proteins from polyacrylamide gels to nitrocellulose sheets. Proc Natl Acad Sci USA 76: 4350-4354 (1979).

34. Vaitukaitis JL: Production of antisera with small doses of immunogen: multiple intradermal injections. Meth Enzymol 73: 46-52 (1981).

35. Van der Plas J, Bovy A, Kruyt F, de Vrieze G, Dassne E, Klein B, Weisbeek P: The gene for the precursor of plastocyanin from the cyanobacterium Anabaena sp. PCC7937: isolation, sequence and regulation. Mol Microbiol 3: 275-284 (1989).

36. Van der Plas J, de Groot R, Woortman M, Cremers J, Borrias M, van Arkel G, Weisbeek P: Genes encoding ferredoxins from Anabaena sp. PCC 7937 and Synechococcus sp PCC 7942: structure and regulation. Photosynth Res 18: 179-204 (1988).

37. Wessels JSC: Isolation of a chloroplast fragment with $\mathrm{NADP}^{+}$-photoreducing activity dependent of plastocyanin and independent of cytochrome f. Biochim Biophys Acta 126: 581-583 (1966).

38. Williams JGK: Construction of specific mutations in photosystem II photosynthetic reaction center by genetic engineering methods in Synechocystis 6803. Meth Enzymol 167: 766-778 (1988).

39. Wynn RM, Malkin R: Interaction of plastocyanin with PS I: a chemical cross-linking study of the polypeptide that binds plastocyanin. Biochemistry 27: 5863-5869 (1988). 